\title{
Good practices in civil planning and crisis management in the world and their implementation in Poland
}

\author{
GRZEGORZ KUNIKOWSKI ${ }^{1}$ (iD https://orcid.org/0000-0002-3660-7117 \\ KATARZYNA ROSTEK ${ }^{2}$ (D) https://orcid.org/0000-0002-7608-738X
}

Warsaw University of Technology, Faculty of Management

\begin{abstract}
The aim of the article is (1) to examine the approach to civil planning in Poland and abroad, including the implementation of the EU Civil Protection Mechanism in Poland, which is reflected in a project of the civil protection act, as well as (2) the review and identification of good practices in the world that can have a beneficial impact and be used in Poland. The research was carried out using the desk research method. The analysis of the existing solutions and identification of good civil planning practices in the world was carried out according to selected dimensions of the civil planning, including: contemporary model concepts of the civil crisis management, including military aspects, analytical planning methods, solutions in the field of knowledge transfer, the policy of financing institutional structures responsible for security and emergency response, technical and organisational improvements. The research has shown that the traditional formula based on the preparation of the required plans is inadequate to pace of changes occurring in the environment, including new threats, but also the ability to transfer solutions and good practices to Poland.
\end{abstract}

Paper type: research article

Key words: civil planning, crisis management, civil defence.

${ }^{1}$ grzegorz.kunikowski@pw.edu.pl

2 katarzyna.rostek@pw.edu.pl 


\section{Introduction}

According to the civil law in Poland, civil planning is defined as "the entirety of organisational undertakings aimed at preparing public administration for crisis management and planning support for the Armed Forces of the Republic of Poland in the event of their use, and planning the use of the Armed Forces of the Republic of Poland to implement crisis management tasks" (Journal of Laws of 2007, no. 89, item 590, as amended 2007 article 3, point 4). Considering the institutions involved, crisis management is one of the tasks of public administration, constituting an element of national security management. It concerns preventing crisis situations, preparing to take control over them by implementing planned actions, reacting in the event of crisis situations, resolving their consequences and reconstructing critical resources and infrastructure (Kosieradzka \& Zawiła-Niedźwiecki, 2016, p. 371).

The aim of the article is to examine the approach for civilian planning in terms of existing regulations and the draft law on civil protection, with particular emphasis on crisis management in Poland and abroad, as well as the indication of good practices in the world that can have a beneficial impact and be applied in Polish conditions. The article considers the synthesis of analytical work carried out in the research project, and its origins were the needs of ordering civil defense issues, observed in the work on the implementation of the EU Civil Protection Mechanism into national legislation, as evidenced by the draft law on civil protection. This project has been subject to a detailed analysis due to the expectations that it will solve a number of issues including competence problems, as well as the fact that it contains current, global trends of crisis management with a large share of public administration.

The analysis was conducted by the desk research method. The scope of the literature reviewied includes national legal regulations (applicable and in the case of civil protection - relevant drafts), the results of research projects in the area of security and crisis management, national and foreign literature on crisis management. Analysis of the solutions and identification of world-wide civil planning good practices (Kąkol, et al., 2016; Kunikowski, et al., 2016) was developed according to selected civil planning aspects, as follows:

- selected concepts of a civil crisis management including military,

- analytical methods used in civil planning,

- approaches to knowledge transfer and competence building,

- financing at the national and local level,

- implemented technical and organisational improvements. 


\section{Civil planning in Poland - present state}

Civil planning is directly related to crisis management involving public administration. According to the legal definition of civilian planning, the Armed Forces play a significant role cooperating with public administration and two types of situations - the use of the Armed Forces in a crisis situation and the support of the Armed Forces in the event that they are used. The second case, although the legislator does not say so explicitly, concerns an armed conflict. The issue of moving away from the militarization of crisis management has a broader historical context and concerns not only Poland but the global trend that results from changing the nature of threats.

In the field of civil planning, understood as preparation of plans by public administration, two basic planning obligations should be distinguished, i.e. preparation of crisis management plans and civil defence plans. While crisis management plans are meticulously prepared, which results from legal regulations (Journal of Laws of 2007, no. 89 , item 590, as amended article 4, point 1), many civil defence plans are neglected. Public administration, voivodships and starostas/counties also have a statutory obligation to agree on rescue plans, for which the voivodship, poviat or municipal commanders of the State Fire Service are responsible as representatives of the National Fire and Rescue System (Journal of Laws of 2017, item 1319).

The poor state of civil defence results both from the lack of legal regulations and the agreement on a comprehensive concept of the functioning of civil defence in Poland. The post-audit remarks formulated by the Supreme Audit Office say that "civil defence functions only on paper" (Supreme Audit Office, 2012a, 2012b, 2013). Critical remarks are expressed equally rigorously, e.g.: "One of the biggest problems in organising the civil protection system in Poland is the lack of comprehensive statutory regulations in this area. The current legal solutions in this respect go back to the provisions of the $20^{\text {th }}$ century from the communist period of Władysław Gomułka's" and, that "Poland is virtually defenceless in the event of a natural, ecological or technical disaster, the consequences of which would affect the area of several voivodships" (Jagnieża, 2015).

In the broader sense of civil protection, in the event of large-scale incidents, an urgent problem is indicated by the lack of statutory regulations, which would be, not only formal authorisation for detailed operational plans, but would also specify in a comprehensive manner organisational principles, institutional and administrative responsibility and financing of activities. One can speak of a dispute over the role of the National Firefighting and Rescue System (NFRS), in particular State Fire Service (SFS), in the system of civil protection, which involves taking over the tasks of the former civil defence and is determined by the militarization of the fire brigade. The work on the draft law, regulating the civil defence organisation commenced in 2006, has not yet ended with the adoption of regulations, which result in no consensus on the concept in this area of the state security. At present, no civilian defence is 
explicitly mentioned, only through the prism of the issue of civil protection, which is also the result of the EU Civil Protection Mechanism (OIL 347, 20.12.2013, pp. 924947). Nevertheless, the draft law on civil protection of 2014 has been abandoned.

Critical remarks also concern the number and consistency of plans to be developed. The tasks of public administration include "Ensuring consistency between crisis management plans and other plans drawn up in this area by competent public administration authorities, whose implementation obligation results from separate regulations." (Journal of Laws of 2007, no. 89, item 590, as amended 2007 article 4, point 1, sub. 6). "The development of crisis management plans does not exempt from duties of planning related to other security areas of the civil sphere, due to the multitude of plans set out for implementation in legal regulations" (Kosowski, 2013 , p. 59). As a result, the preparation of documents creates problems with ensuring their consistency, in addition "there is a repeatability of data (area analysis, risk analysis, forces and measures, etc.) in different plans, referring to the same area (level of state management), with some of them the plans are public documents, while others are of an appropriate classification level" (Kosowski, 2013, p. 59). ${ }^{3}$

Solutions to the problem of the plans consistency can vary in detail. First of all, one can limit the number of documents, which Dynak (2013, p. 105) defines as follows: "having in mind the multitude of planning documents that currently exist in the poviat, commune (47 plans), it is reasonable to merge and create one comprehensive operational document in the form of: Poviat, communal plan for safety management for peacetime, crisis and war." Secondly, it is possible to implement tools supporting planning processes, facilitating both the preparation of plans and facilitating the coordination of arrangements, as well as the verification of cohesion (through unification of structure, ordering concepts, cataloguing threats, etc.), which is the subject of ongoing research (Wróblewski, Kędzierska, \& Połeć, 2014) whether the project funded by the National Centre for Research and Development (NCRD) implemented by the WUT Management Department and the Medcore company. Numerous inspirations can be found in the area of information management within the framework of the NFRS or the Central Reporting Application (CRA) (Galicki \& Świszcz, 2013; Paszkowski, 2014).

The comparative analysis of emergency systems models conducted by the authors in a preliminary study (Kunikowski, Rostek, \& Kisilowski, 2016) showed that, it is imperative to improve the effectiveness of the Polish rescue system, especially in terms of safety and minimising fatal accidents. Therefore, taking as a starting point the existence of a problem in the scope of insufficient effectiveness of the civil planning system, which is largely responsible for the operation of emergency services and the effectiveness of implemented prevention, a question should be posed: What patterns and good practices from other countries can and should be adopted in Poland?

3 The analyzed the draft law on civil protection, is envisaged the imposition of obligations to prepare further plans for civil protection. 


\section{Analysis of the project of the civil protection act in Poland}

The government draft assumptions for the act on civil protection, prepared in March 2014 by the Minister of the Internal Affairs (Minister of the Interior, 2014b), was in April 2014 directed to inter-ministerial consultations and consultations - to secret services, trade unions and individual voivodes. After having considered the comments, a second version of the draft assumptions was prepared and published (Minister of the Interior, 2014a). The aim of the project, in its second version, is "complex regulation of the issue of civil protection at the level of a statutory act," including through:

- introduction to the legal order of the defined concept of "civil protection,"

- clear definition of tasks in the field of civil protection for public administration bodies,

- an indication of the bodies responsible for the implementation of tasks in the field of civil protection, including defining tasks in the field of civil protection at the level of the community, poviat, province and country,

- defining a new method of state implementation of civil defence tasks, referred to in the Additional Protocol on 12 August 1949 to the Geneva Conventions on the protection of victims of international armed conflicts (Protocol I). It is envisaged to introduce into the legal order a mechanism for giving statutory entities, that perform tasks in the field of civil protection, the status of entities performing civil defence tasks during war.

In order to implement these regulations, it was expected that changes to the existing regulations would be necessary. The implementation of tasks in the field of civil protection will cover three main areas of tasks:

- monitoring, informing and warning about threats,

- saving life, health, property and the environment,

- providing emergency humanitarian aid.

In the current legal order, the NFRS is the basic formula for the implementation of tasks in the field of civil protection. The legislator states that "experience gained over the last dozen or so years of system operation, including new challenges for emergency services and organizations in various areas of rescue, indicate the need to use the NFRS formula more widely than before, including in the field of humanitarian aid and participation in the process of ensuring the availability of equipment reserves, intended for use in order to implement the task of civil protection, as well as in the scope of shaping appropriate safeguards in the event of danger" (Minister of the Interior, 2014a, p. 4).

In the area of planning, the project assumes the introduction of the obligation to prepare "Rescue and civil protection programs" at the national, provincial and poviat level. Such programs would set priorities in the implementation of civil protection tasks, ways to accomplish these tasks, and the necessary resources. The guiding principle of the proposed solutions is the use of existing state resources, in 
particular the NFRS, State Medical Rescue (Państwowe Ratownictwo Medyczne), Emergency Notification System (System Powiadamiania Ratunkowego) and the potential of associations (e.g. volunteer fire departments) and non-governmental organizations (e.g. social rescue organizations) to create conditions for effective cooperation (Minister of the Interior, 2014a, pp. 1-2). The legislator claims that "with respect to civil protection matters, the archaic nature of currently adopted legal solutions should be additionally improved, which also causes certain complications of the functioning of civil defence. The current legal status causes illegibility of competence and responsibility in this area" (Minister of the Interior, 2014a, p. 2).

In the assumptions for the draft of the civil protection act, prepared by the Civil Defence of the Country, we read that "costs that should be spent in order to create and develop (in accordance with the normative) civil defence formation for general tasks and specialised formation referred to in the Act on the general obligation to defend the Republic of Poland would amount to nearly 4001283000 PLN at one time. However, the funds currently allocated in the state budget for civil defence tasks amounts to 6905000 PLN" (data included in the Budget Act for 2014). In terms of coordination, the challenge is to provide strength and resources in atypical and large-scaled events. An example of problems in this area is the coordination of delaying retention reservoirs during floods, when indirect services, i.e. Powiat Coordination Centres, are ineffective, because limited to transferring information between "municipalities" and "voivodship", omitting other aspects of their operation.

\section{Identification and characteristics of good practices in the world}

The content presented below is the summary of an international review, aimed at identifying good practices that could be included in the national civilian planning process (Kąkol, et al., 2016; Kunikowski, et al., 2016).

\subsection{A four-stage crisis management model and the involvement of armed forces}

In the world-common approach to crisis management as part of a civilian planning, four basic stages are considered: 1) prevention, 2) planning, 3) response, 4) recovery. A slightly different approach is used in the United Kingdom, where the civil protection system is based on the concept of integrated crisis management, which consists of the integration of six related areas of action: 1) anticipation, 2) assessment, 3) prevention, 4) preparation, 5) response and 6) reconstruction. The inclusion of prediction and assessment elements demonstrates the intentions of enhancing preventive actions, which is an extremely successful approach. 
In the Western World, there has been a withdrawal from the military nature of crisis planning, a universal approach in terms of threats and openness to public administration and society, including non-governmental organizations. The phenomenon of moving away from civil defence for the civil protection is described in more detail (Alexander, 2002). Similarly, it happens in Poland (Gołębiewski, 2015, p. 10) boiling down to three aspects, i.e. abandonment of military planning to consider all threats, openness to civilian administration and society, and exchange of the staff involved in civilian planning and crisis management from military to civilian, accompanied by high professionalism. A natural phenomenon is also cooperation with crisis management centres of retired representatives of uniformed services. They make a significant contribution in the form of practical experience.

In cooperation of public administration with the armed forces, in the field of crisis management, a principle of engaging the army in situations where the emergency services become inefficient and unavailable is used. For efficient cooperation it is necessary not only to develop rules for the use of armed forces and to define unambiguous managerial competences, but also to conduct exercises and create opportunities for establishing contacts and cooperation. ${ }^{4}$ In events requiring reacting with the use of significant forces and resources from outside the region, paramilitary formations, such as civil defence, play an important role alongside civil services. This is also the reason for the importance of the draft law presented earlier.

\subsection{Analytical methods used in civil planning}

It is important to emphasize that plans should define the implementation of processes and not focus solely on providing resources. According to Alexander (2005, p. 165), the plan "should not be a list of resources but should define the procedures necessary for effective management in crisis situations." In terms of standardisation of civil planning (Alexander, 2005, pp. 161-165) proposed 18 planning axioms in crisis management and a model of the state of evolution of the civil protection system (Alexander, 2015, pp. 279-280; 2016, p. 119). ${ }^{5}$

A typical crisis management plan, in the analytical part, includes risk assessments and scenario analyses. Risk assessments are an integral part of crisis management planning. The risk assessments are recommended, which as a starting point, use the approach of sector analyses, using information on past events and national risk registers (Baubion, 2013, p. 10). Some countries publish national risk

4 The National Crisis Management Plan (NSDC) sets out crisis response procedures that take into account the use of the Armed Forces and the rules for cooperation of institutions involved, including international ones (RCB, 2017, pp. 297-321).

${ }_{5}$ According to the cited model of the state of development of the civil protection system, the state of Poland, can be assessed to be at the transition level of advanced functionalities, but before the threshold of excellence and professionalization, where there is full efficiency, comprehensive and complete integration with other systems. 
registers. The pioneer in this respect was the United Kingdom, with a register made publicly available in 2008. Other publishing countries are Norway, Switzerland, Canada, the United States, the Netherlands, France, Germany and Sweden (Baubion, 2013, p. 12). ${ }^{6}$

A common element of plans is scenario analysis. According to the recommendation of the Organization for Economic Co-operation and Development (OECD), scenario analysis is a continuation of the risk assessment. Its important aspect is the impact and significance of cooperation between institutions and emergency services as well as the resource approach based on the assessment of resources held in the context of their use in situations of analysed crisis events (Baubion, 2013, p. 13).

\subsection{Knowledge concentration and improvement of competencies}

An important element of the civil crisis management system is the possession of strong competence centres. The model units of this type are the American Federal Crisis Management Agency (FEMA) and the Danish Emergency Management Agency (DEMA). These institutions prepare the guidelines and methodologies for the needs of public administration, including detailed guidebooks explaining the preparation of plans (FEMA, 2004, 2011, 2013). They also carry out specialist training activities. In other countries such functions are performed by specialised ministerial units, e.g. in Germany it is the Federal Office for Civil Protection and Disaster, and in Poland - the Government Security CENTRE (Rządowe Centrum Bezpieczeństwa, RCB). Competencies and specialist knowledge of employees of these units are complemented by external experts in the field.

In Anglo-Saxonian countries, there is a dedicated profession involved in crisis management planning - Emergency Planning Officer. More on the historical context, the tasks carried out, the necessary competencies and the scope of responsibility of the crisis management specialist has been written by Dillon, Dickinson, Williams, and Still (2014, pp. 6-14).

\subsection{Financing at the national and local level}

The structure of expenses incurred by individual European Union countries (Table 1) illustrates, in addition to the economic potential, the security policy being pursued. Table 1 presents expenditures per capita, borne for military purposes, civil defence, police and fire brigade. The following tables reflect the countries' approach to the implementation of security policy through the financing structure of the military, internal and emergency sectors.

${ }^{6}$ In Poland, descriptive characteristics of hazards and risk characterization are included in the previously mentioned National Crisis Management Plan (Krajowy Plan Zarządzania Kryzysowego). 
Table 1 Expenditures for security institutions in EUR/citizen in 2016

\begin{tabular}{|c|c|c|c|c|}
\hline Country & Military & Civil Defence & Police & Fire Service \\
\hline European Union & 351.31 & 1.52 & 272.27 & 59.05 \\
\hline Austria & 226.84 & 0.32 & 277.21 & 69.60 \\
\hline Belgium & 288.90 & - & 388.35 & 63.13 \\
\hline Bulgaria & 72.45 & 0.01 & 72.72 & 20.47 \\
\hline Croatia & 130.06 & - & 155.47 & 20.52 \\
\hline Cyprus & 317.3 & 5.87 & 285.48 & 30.77 \\
\hline Czech Republic & 105.99 & 0.46 & 145.39 & 40.77 \\
\hline Denmark & 513.13 & 19.86 & 271.36 & 34.00 \\
\hline Estonia & 375.64 & - & 157.38 & 39.74 \\
\hline Finland & 472.59 & 7.10 & 211.45 & 108.09 \\
\hline France & 508.23 & 2.20 & 313.83 & 90.34 \\
\hline Greece & 343.91 & - & 232.28 & 47.33 \\
\hline Spain & 205.23 & - & 291.80 & 37.42 \\
\hline Holland & 408.43 & - & 345.47 & 97.03 \\
\hline Ireland & 158.07 & 6.75 & 355.51 & 41.74 \\
\hline Lithuania & 171.29 & 0.45 & 74.19 & 29.64 \\
\hline Latvia & 200.73 & 2.55 & 149.18 & 28.22 \\
\hline Malta & 133.43 & - & 147.69 & 17.12 \\
\hline Germany & 355.38 & 0.12 & 289.4 & 92.18 \\
\hline Norway & 909.82 & 37.99 & 369.84 & 149.22 \\
\hline Poland & 173.93 & 0.10 & 126.92 & 20.41 \\
\hline Portugal & 146.79 & - & 187.29 & 24.32 \\
\hline Romania & 74.95 & - & 86.69 & 22.04 \\
\hline Slovak Republic & 140.64 & 0.41 & 157.47 & 25.76 \\
\hline Slovenia & 131.74 & 13.32 & 181.10 & 26.74 \\
\hline Switzerland & 512.93 & 56.79 & 509.06 & 87.45 \\
\hline Sweden & 484.52 & 21.08 & 278.74 & 97.66 \\
\hline Hungary & 77.10 & 0.58 & 150.98 & 28.67 \\
\hline Great Britain & 657.80 & 2.49 & 363.51 & 51.97 \\
\hline Italy & 348.26 & 0.08 & 320.38 & 50.79 \\
\hline
\end{tabular}

Source: own work based on Eurostat, 2018, passim.

The financial data of countries listed according to the highest expenditures are presented in Figures 1-4. 
Military - financing by the state (2016)

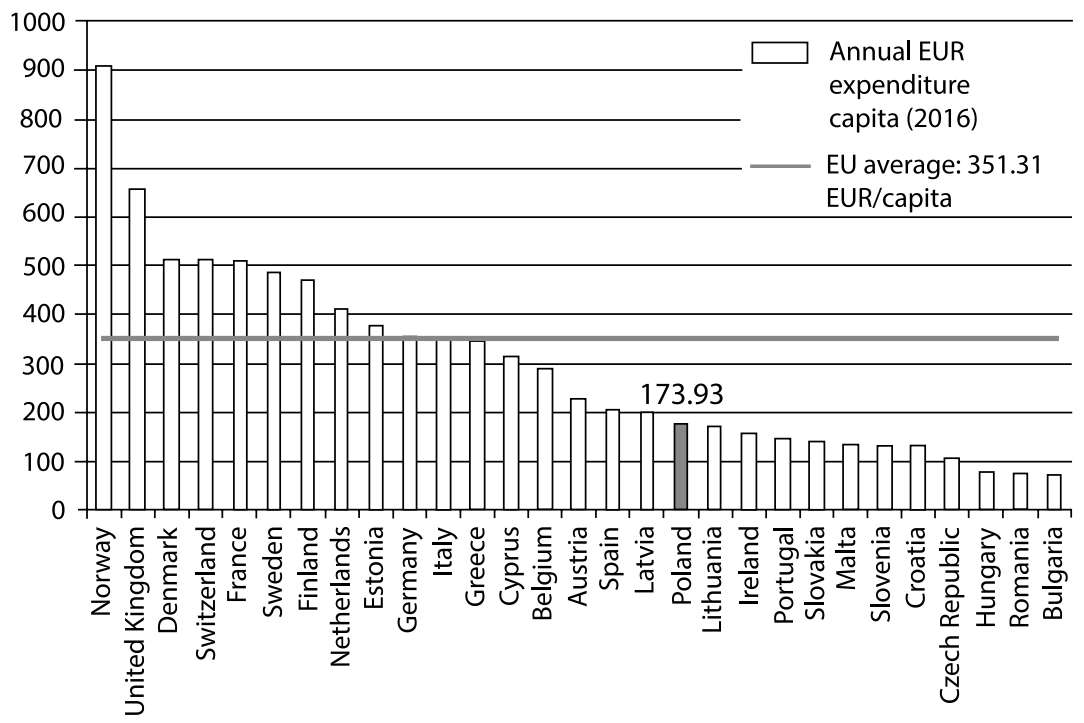

Figure 1. Annual expenditures for the army in 2016.

Source: own work based on Eurostat, 2018, passim.

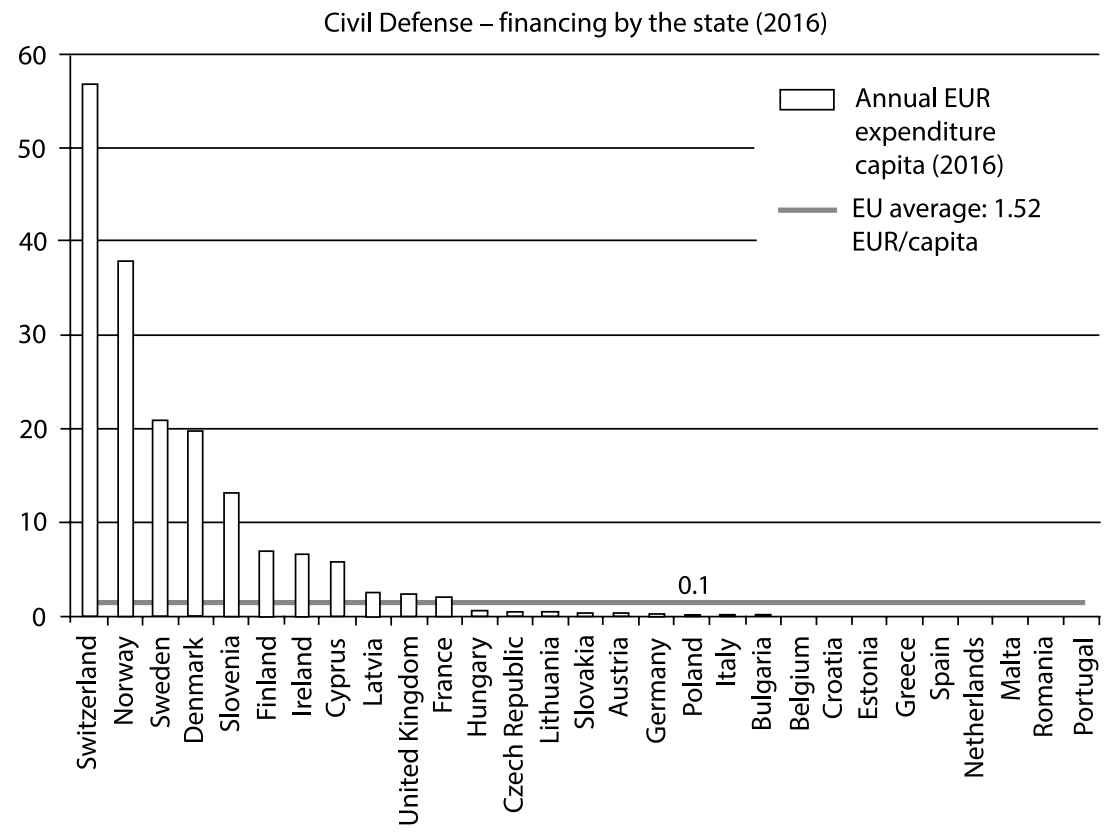

Figure 2. Annual expenditures for the civil defence in 2016.

Source: own work based on Eurostat, 2018, passim. 
Police - financing by the state (2016)

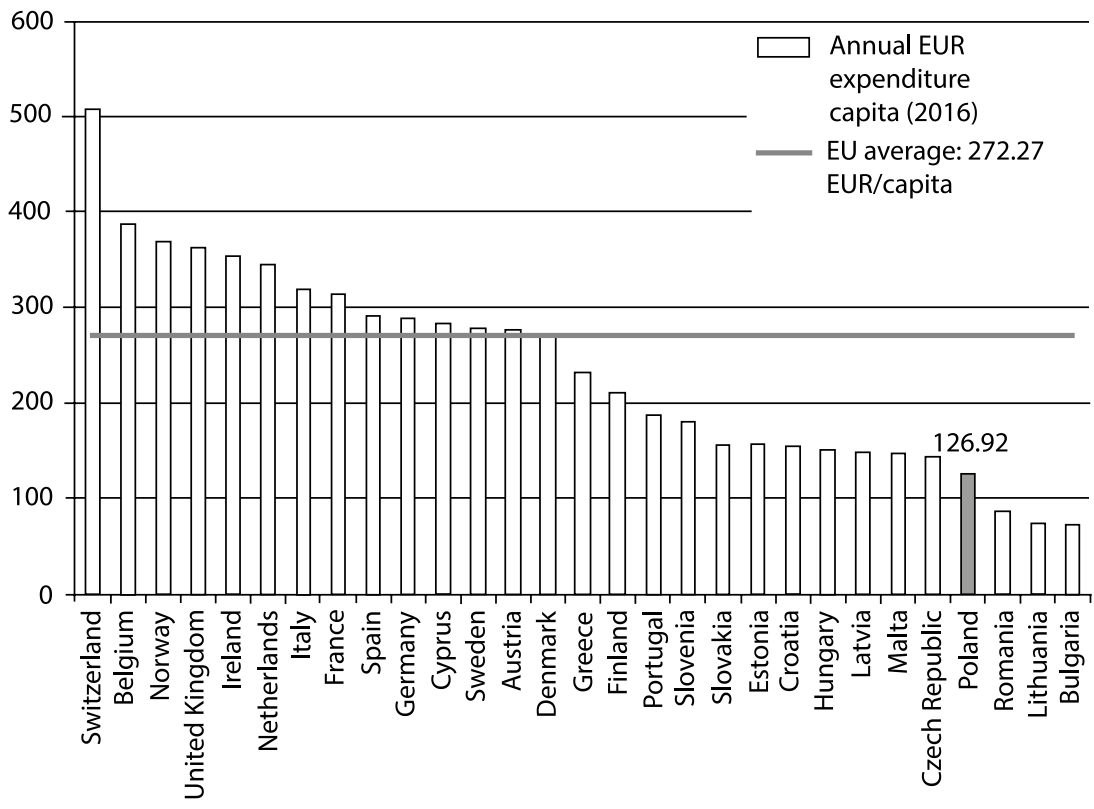

Figure 3. Annual expenditures for the police in 2016.

Source: own work based on Eurostat, 2018, passim.

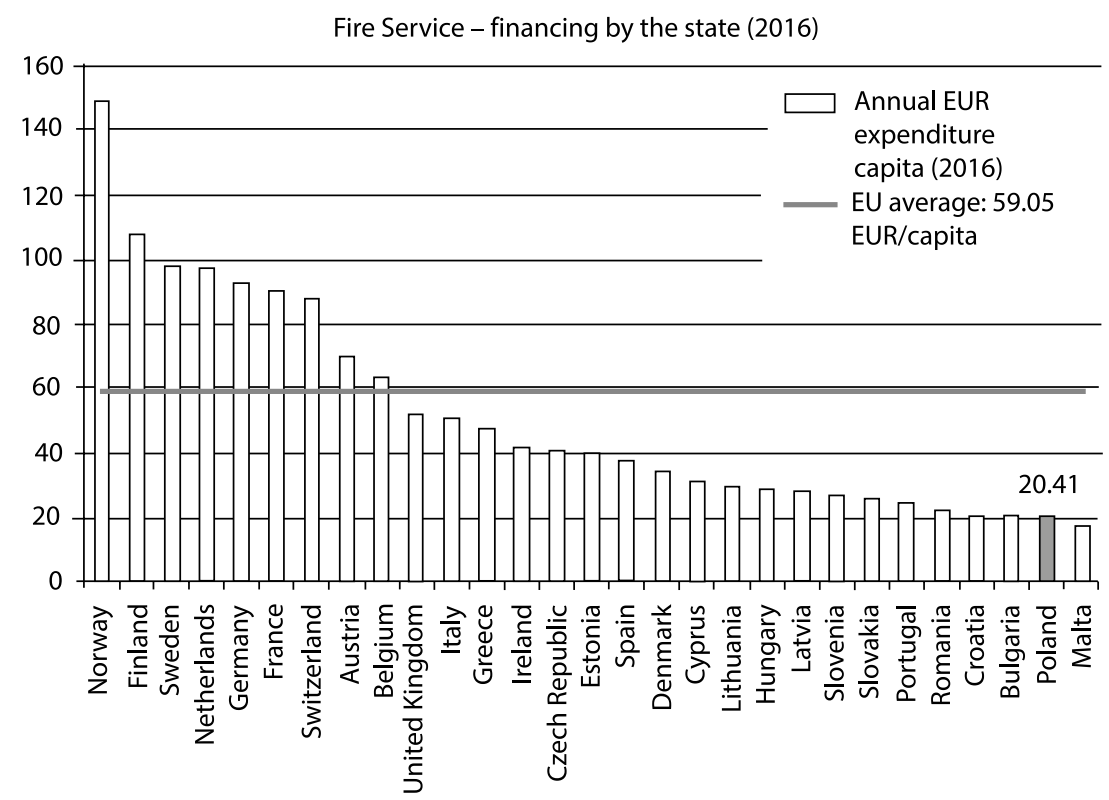

Figure 4. Annual expenditures for the fire service in 2016.

Source: own work based on Eurostat, 2018, passim. 
Poland is slightly higher than the middle of the group, and always below the EU average. This shows the undervaluation of those areas and activities that are responsible for the security and protection of the civil protection.

These data show that military costs are higher, above $20 \%$, in relation to the costs incurred for the functioning of the police. Such a financing structure also shows that expenditures spent on the police are rising, which confirms the significance of internal security. Considering spending, it can be seen that civil defence is marginalised in most countries. The following countries clearly stand out: Switzerland, the Scandinavian countries, Slovenia and Ireland. In addition, expenses related to the police and fire brigades reflect the economic position of the individual countries.

In the operational perspective, financing of crisis-related activities should be considered in terms of prevention measures and funds for the costs of rescue and recovery operations. In this context, it is worth mentioning the refinancing principles of costs borne by local government units in Great Britain in crisis situations. This system is called the Bellwin plan (Olejniczak, 2012). It assumes that granting of financial aid is not automatic. It covers expenditure confirmed by accounts, resulting from the necessary measures to be taken and immediate action. The costs of overtime, commissioned work and the participation of volunteers in the work related to crisis situations can also be reimbursed. Financial assistance only concerns the costs incurred above a certain threshold that has been adopted and to which the territorial unit has to cope with independently (Skomra, 2007, pp. 11-12).

While continuing the financing theme, the participation of private companies and the formula of public-private partnership, for example, in emergency medical services or municipal services, should be considered. One cannot clearly indicate whether the provision of medical services by private entities is a better solution. Therefore, it would be worth checking in practice the efficiency and effectiveness of the public-private partnership model in less sensitive areas than rescue. For example, effective functioning in the area of municipal services, may be a pass to take up activities in selected areas of emergency medical services. It is worth mentioning here the example of Denmark, where a significant part of the medical emergency service ( $2 / 3$ of communities) is provided by private companies (these are also companies known and present in Poland, e.g. FALCK). In the absence of legal barriers, companies, including international ones, operating on the market of medical services in the commercial model are becoming more active. Such companies have effective model and standardised patterns of operation. At the same time, some care should be taken not to lose the mission and the priority of helping at the expense of the economic account, and to bear in mind that emergency medical services are part of the national health care system. ${ }^{7}$

${ }^{7}$ Quick and efficient first aid and quick delivery of the patient to the hospital is still only the first stage of medical help. 
In the area of prevention, it is important to have budgets in local government units that allow systematic replenishment of stocks. Interesting solutions are used in this area in Finland, where government institutions, companies and other organizations are also required to include in the annual budgets' items related to the financing of emergency planning and other preparatory measures.

\subsection{Selected improvements of operational activities of crisis management and rescue operations}

During the analysis of source materials, the authors came across relatively simple, tested abroad practical solutions, improving the functioning of institutions and services related to crisis management and rescue.

An improvement that makes it possible to shorten the time of traveling to the patient, used in the United States is called the "Green Wave" city system. The rescue vehicle is equipped with a transmitter that sends a signal to the receiver installed at the traffic lights. The signal sent causes switching on the green light path. In the other directions, red lights are lit. In addition, a lamp is turned on to signal other drivers, approaching a privileged vehicle (Maślanka, 2007, p. 28).

The implementation of ICT solutions into practice goes beyond mere communication. In the United States, for example, technical measures used in emergency services allow paramedics to stay in touch with their physician and even with a whole team of specialists. Special cameras and medical equipment allow the medical team to monitor the location of the event and information about the patient's state of health. Radio communication between the rescuer and the physician improves the conduct of rescue operations at the scene of the accident. Similar solutions are found in the UK, and in addition, most ambulances are equipped with navigation systems that allow the medical rescue team to reach the scene much faster.

In the field of civil planning, especially for operational elements of crisis management plans, quantitative information of forces and resources needed to react in selected situations may be useful. An example is data published in the manuals on organising humanitarian aid (UNHCER, 2007, pp. 544-553), which may be useful for the planners not specialising in engineering fields. ${ }^{8}$

${ }^{8}$ It is about information about, e.g. daily demand for food and water, personal requirements of rescue personnel based on the number of injured people, logistics data on the volume of transport means, dimensions of resources needed in crisis situations, etc. 


\section{Conclusion and the results}

At this stage, the following crucial national civil emergency problems in the field of crisis management have been identified:

- the lack of the concept of civil defence functioning in this variant of explicit remodelling of the remains of existing structures, e.g. based on NFRS with the dominant role of the State Fire Service (which is sometimes referred to as the "militarization of the fire brigade") as part of the announced Civil Protection Act, ${ }^{9}$

- a multitude of current planning responsibilities, which translates into the quality of plans.

The conducted desk research allowed to identify the practices that can be used in Poland.

The conclusion is that the traditional formula based on the preparation of the required plans is inadequate to the dynamic of changes occurring in the environment, including the emergence of new threats, availability of support technologies and delays in the amendment of the law. The environment changes so quickly and unpredictably that plans can be incomplete as soon as they are adopted. In addition, the number and diversity of crisis management plans makes it difficult to maintain consistency between them. Technological solutions are available (cited examples of implementations in emergency services), which allow creating dynamic, constantly updated systems supporting the work of personnel dealing with crisis management.

Selected solutions used in other countries may be treated as examples worth attention in the perspective of the possibility of their implementation and adaptation in Poland. However, it is necessary to conduct an in-depth analysis, and, in particular, to obtain opinions and verifications of judgments by specialists, civilian practitioners of crisis management and representatives of uniformed services.

As it can be seen from the above considerations, there are many questions as well as possibilities, and there are even more variants of the answers. Therefore, it is reasonable to conduct research focused on foreign solutions, indicating the possibility of their adaptation in Polish conditions.

\section{References}

Alexander, D. (2002). From civil defence to civil protection - and back again. Disaster Prevention and Management: An International Journal, 11(3), 209-213.

Alexander, D. (2005). Towards the development of a standard in emergency planning. Disaster Prevention and Management: An International Journal, 14(2), 158-175.

9 The role of the Territorial Defense Force (Wojska Obrony Terytorialnej) in crisis management remains open, which was not a broadly discussed issue in the article. 
Alexander, D.E. (2015). Evaluation of civil protection programmes, with a case study from Mexico. Disaster Prevention and Management, 24(2), 263-283.

Alexander, D.E. (2016). How to Write an Emergency Plan. Edinburgh, England: Dunedin Academic Press.

Bąk, D., et al. (2015). Projektowanie systemu ratowniczego. Wydawnictwo Centrum Naukowo-Badawczego Ochrony Przeciwpożarowej im. Józefa Tuliszkowskiego Państwowego Instytutu Badawczego.

Baubion, C. (2013). OECD Risk Management. Strategic Crisis Management. OECD.

Dillon, B., Dickinson, I., Williams, J., \& Still, K. (2014). Blackstone's Emergency Planning, Crisis, and Disaster Management ( $2^{\text {nd }}$ ed.). Oxford: Oxford University Press.

Dynak, R. (2013). Przygotowanie struktur kierowania do działania w sytuacjach kryzysowych na szczeblu lokalnym. In Planowanie cywilne $w$ systemie zarzadzania kryzysowego. Józefów: Wydawnictwo Centrum Naukowo-Badawczego Ochrony Przeciwpożarowej im. Józefa Tuliszewskiego, pp. 87-108.

Eurostat (2018). Retrieved from: https://ec.europa.eu/eurostat [accessed: 30.07.2018].

FEMA (2004). Are You Ready? An In-depth Guide to Citizen Preparedness. Federal Emergency Management Agency.

FEMA (2011). Emergency Planning. Emmitsburg, MD: CreateSpace Independent Publishing Platform.

FEMA (2013). Local Mitigation Planning Handbook. Federal Emergency Management Agency.

Galicki, K., \& Świszcz, G. (2013). Usprawnienie procesu obiegu informacji w systemie zarządzania kryzysowego. Przegląd Bezpieczeństwa Wewnętrznego, ABW, (9), 318-323.

Gołębiewski, J. (2015). Zarządzanie kryzysowe na szczeblu samorządowym: teoria i praktyka. Warszawa: Difin.

Jagnieża, A. (2015). Program Zamiast Ustawy. Ochrona Ludności - Zaniechań Ciąg Dalszy. Retrieved from http://www.defense24.pl/170757,program-zamiast-ustawy-ochrona-ludnosci-zaniechan-ciag-dalszy [accessed: 8.10.2016].

Journal of Law of 2007, no. 89, item 590, as Amended the Crisis Managament Act of 26 April 2007.

Journal of Law of 2017, item 1319, Regulation of the Minister of Interior and Administration of 3 July 20172017 on the detailed organization of the National Firefighting and Rescue System.

Kąkol, U., Kisilowski, M., Kunikowski, G., \& Uklańska, A. (2016). Diagnoza stanu planowania cywilnego w Polsce i na świecie - raport projektu NCBiR. Warszawa: Politechnika Warszawska, Wydział Zarządzania.

Kosieradzka, A., \& Zawiła-Niedźwiecki, J. (eds.) (2016). Zaawansowana metodyka oceny ryzyka w publicznym zarządzaniu kryzysowym. Kraków-Legionowo: Edu-Libri.

Kosowski, B. (ed.). (2013). Planowanie w systemie zarządzania bezpieczeństwem sfery cywilnej. In Planowanie cywilne w systemie zarządzania kryzysowego. Józefów: Wydawnictwo Centrum Naukowo-Badawczego Ochrony Przeciwpożarowej im. Józefa Tuliszewskiego, pp. 89-106.

Kunikowski, G., Rostek, K., \& Kisilowski, M. (2016). Analiza modeli systemów ratownictwa $w$ Polsce $i$ w wybranych krajach świata - raport projektu NCBiR. Warszawa: Politechnika Warszawska, Wydział Zarządzania.

Maślanka, M. (2007). Organizacja systemu ratownictwa medycznego w Stanach Zjednoczonych na przykładzie Erie w Pensylwanii. Na Ratunek. Retrieved from: http://docplayer. pl/3079912-Organizacja-systemu-ratownictwa-medycznego-w-stanach-zjednoczonychna-przykladzie-erie-w-pensylwanii-cz-1.html [accessed: 30.07.2018]. 
Minister of the Interior (2014a). Projekt założeń do projektu ustawy o ochronie ludności (11.08.2014).

Minister of the Interior (2014b). Projekt założeń do projektu ustawy o ochronie ludności (19.03.2014).

Official Journal of the European Union L 347, 20.12.2013, Decision No. 1313/2013.EU of the European Parliament and of the Council of 17 December 2013 on a Union Civil Protection Mechanism.

Olejniczak, J. (2012). Schemat Bellwina jako mechanizm gwarantowania środków finansowych dla JST w Wielkiej Brytanii. Zeszyty Naukowe Wyższej Szkoły Bankowej we Wrocławiu, (nr 29 Finanse samorządu terytorialnego), 105-115.

Paszkowski, A. (2014). Centralna Aplikacja Raportująca - wersja 2.0. Biuletyn Kwartalny RCB, (8), 15-19.

RCB (2017). Krajowy plan zarządzania kryzysowego 2017 Część A. Warszawa: Rządowe Centrum Bezpieczeństwa.

Skomra, W. (2007). Funkcjonowanie organów administracji publicznej w czasie klęsk żywiołowych w wybranych krajach. Bezpieczeństwo i Technika Pożarnicza, 5(1), 7-55.

Supreme Audit Office (2012a). Przygotowanie struktur obrony cywilnej do realizacji zadań $w$ okresie wojny i pokoju (No. KPB-4101-02/2011). Warszawa: NIK.

Supreme Audit Office (2012b). Wykonywanie przez organy administracji publicznej zadań w zakresie zarzadzania kryzysowego.

Supreme Audit Office (2013). Raport NIK nr KPB-4114-01-00/2012 Przygotowanie systemu ochrony ludności przed klęskami żywiołowymi oraz sytuacjami kryzysowymi (20.06.2013). Warszawa.

UNHCER (2007). Handbook for Emergencies. Geneva: The UN Refugee Agency.

Wróblewski, D., Kędzierska, M., \& Połeć, B. (2014). Teleinformatyczny zintegrowany system budowy planów zarządzania kryzysowego - badania i projektowanie. In Przegląd wybranych dokumentów normatywnych z zakresu zarządzania kryzysowego i zarządzania ryzykiem wraz z leksykonem: Książki: CNBOP (pp. 7-30). Józefów: Wydawnictwo Centrum Naukowo-Badawczego Ochrony Przeciwpożarowej im. Józefa Tuliszewskiego.

\section{Notes about the Authors}

Grzegorz Kunikowski - received the title of doctor of economic in the management discipline in 2015 from the Faculty of Management Warsaw University of Technology. He has experiences of participation in national and international research projects in the field of civil planning, crisis management and renewable energy.

Katarzyna Rostek - an employee of the Faculty of Management at the Warsaw University of Technology. A specialist in the field of business analytics, intelligent methods of decision support and management of communication and knowledge in the organization. Operational manager and member of project teams in the field of design and implementation of decision support systems, SMEs competitiveness analysis, risk analysis and analysis of commercial potential of products and technological processes. An expert evaluating project applications in international competitions and a reviewer in scientific publications. 